\title{
Court of Appeal
}

\author{
Michèle Causse
}

- Did your lover die?

- Yes she did.

- Did you kill her?

- Idon't know.

- You are not sure?

- No.

- Where did you live at that time?

- In Montréal.

- Did you not live in France before?

- Yes I did.

- Why did you leave France?

- To live with her.

- What happened?

- She was afraid of me, she was afraid of herself. She was afraid of us.

- Do you know why?

- She said "What you are about is not life but illumination. And one cannot live that day by day."

- Did you believe her?

- No.

- Did she object?

- She said "you are so devastatingly true about truth."

- What did she mean?

- She meant she could not stand truth.

- What was the truth?

- Love is ontological.

- What did you do, then?

- I wandered.

- How did you feel?

- Bewildered.

- Did you still love her?

- Yes. 
- Did she know it?

- Yes. I told her.

- Where did you go then?

- I went to an island under a volcano. For a while a while a while. Then I followed a writer friend to Florida. I met Barbara Deming who sheltered me. I listened to her. I listened to Sonia Johnson. I complained that Florida was too flat. I went back to the volcano. I was crawling or lying on the floor. Gaping.

- How long did it last?

- Five years.

- Did your lover ever call you?

- Yes.

- What did she say?

- She said "from the jaws of the ordeal one has slipped only further onto its belly."

- And?

- And "I cannot puncture the remoteness of the present, this now, this you."

- What did you answer?

- That I had only daydreams.

- Why did you go to Montréal?

- To be a few miles away from my lover in New York.

- What did you do in Montréal?

- I went on breaking my bones.

- Did you call your lover?

- Yes.

- Did she come to see you?

- Yes.

- What did she say?

- She said "help."

- Is that all?

- No. She said "In sleep, finally, there is no between."

- And?

- Between us there has been only the connection of dispersal."

- Did you make love?

- Yes.

- How did you feel?

- Like a ship wrecking.

- Did you ask her to live with you? 
- Yes.

- What did she answer?

- She said "yes" she said "no" she said "let us go to India."

- Did you go?

- No.

- And so?

- I was invited to the Québec bookfair. It was April and it was snowing. I spoke on the day of the Stanley Cup final. The bookfair was empty. I said "please, don't bother to read my books because writing means more to the writer than to the reader." Then I thought of Gertrude Stein. A French author came to me and said "you were bold." Her name was Clarisse Nicoidski. The day after the wind was blowing. I went to walk above the river St. Laurent, and all of a sudden, it happened.

- What happened?

- Idid not love my lover anymore.

- What do you mean?

- All of a sudden I was drained out, dried out. Dead.

- Did you tell her?

- Yes.

- Why?

- Because my love was air and breath and she could not live without air and breath.

- What happened next?

- She got sick.

- What do you mean?

- She got liver cancer.

- How did you know?

- She told me on the telephone.

- Did you feel guilty?

- No.

- How old was she?

- Fifty three.

- Was she an alcoholic?

- No. She drank soya milk.

- Did you see her again?

- Yes. After her first leave from the hospital. We went to Mount Desert Island. We walked. We talked.

- What did she say? 
- She said “I don't see any light in your eyes."

- Was it true?

- Yes.

- Did you feel sad?

- I felt sad not to be sad.

- Did she say anything else?

- She said "terror has only itself for its meal."

- Did she know she was going to die?

- We were both already dead.

- Did you tell her the truth?

- Yes.

- How did she react?

- She said "the key word of life is frustration."

- Did you understand what she meant?

- Yes.

- Do you know frustration?

- No. Only deprivation.

- When did she die clinically?

- During the night of the 21st of February 1990.

- What were you doing on that night?

- I was reading the letters of Djuna Barnes to Natalie Barney in a public square in Montreal.

- Did you know she was agonizing?

- Yes I knew.

- Why did you not stay by her side?

- She did not want me to see her. Her stomach had swollen, her hair had fallen, her face had dropped.

- Did you want to go to her?

- No.

- Why?

- I had buried her.

- What was her last word?

- "Help."

- What did you do afterwards?

- On the 21st of February 1991 I went to Tulum in Mexico. I stayed in front of the sea for a while a while a while and I called her.

- Did she answer?

- No. 